\title{
Kampanye Komunikasi Lingkungan melalui Media Tanaman di Desa Karangjompo Kecamatan Tirto Kabupaten Pekalongan
}

\author{
Trimanah*, Mubarok, Genta Maghvira \\ Ilmu Komunikasi, Fakultas Bahasa dan Ilmu Komunikasi, Universitas Islam Sultan Agung, Semarang, \\ Indonesia \\ *Corresponding Author \\ e-mail: trimanah@unissula.ac.id \\ Received: \\ 1 January 202

Revised:
5 April 2021 \\ Accepted: \\ 15 May 2021 \\ Published: \\ 31 May 2021
}

\begin{abstract}
Abstrak
Desa Karangjompo di kecamatan Tirto adalah salah satu desa di Kabupaten Pekalongan yang terdampak banjir selama lebih dari 5 tahun. Salah satu penyebab banjir adalah buruknya perilaku warganya yang masih belum memiliki kesadaran tinggi untuk menjaga kebersihan saluran drainase sehingga tidak berfungsi maksimal. Selain itu kebiasaan warga menggunakan air bawah tanah yang tidak terkontrol telah memperburuk terjadinya land subsidence yang memperparah banjir. Banjir telah merusak fasilitas umum dan rumah warga, serta telah mematikan berbagai tanaman dan tumbuhan yang ada. Desa menjadi minim penghijauan. Tujuan dari kegiatan pengabdian masyarakat ini adalah untuk mengajak warga melakukan penghijauan sekaligus memberikan informasi dan mengedukasi warga mengenai pentingnya menjaga lingkungan melalui kampanye komunikasi lingkungan dengan media tanaman. Evaluasi keberhasilan program dilakukan melalui diskusi yang melibatkan ibu-ibu anggota arisan. Dimana hasilnya menunjukkan bahwa secara umum warga telah menunjukkan perubahan sikap sampai pada tahap konatif, tetapi belum menunjukkan perubahan perilaku sebagaimana yang diarapkan.
\end{abstract}

Kata kunci: kampanye; komunikasi lingkungan; penghijauan; media tanaman

\begin{abstract}
Karangjompo village in Tirto sub-district is one of the villages in Pekalongan Regency that has been affected by flooding for more than 5 years. One of the causes of flooding is the bad behavior of the residents who still do not have high awareness to keep the drainage channels clean so that they do not function optimally. In addition, the uncontrolled habit of using underground water has led to land subsidence which has exacerbated flooding. The floods have damaged public facilities and residents' homes, and have killed various existing plants. The village has minimal greening. The purpose of this community service is to persuade residents to replant as well as inform and educate them about the importance of protecting the environment through a communication campaign with potted plants as media. Evaluation is carried out through discussions involving housewives who are members of arisan. The result was shows that society has changes in their attitudes to the conative stage, but has not shown in behavioral changes as expected.
\end{abstract}

Keywords: campaign; environmental communication; greening; potted plants media

\section{PENDAHULUAN}

Banjir yang telah berlangsung selama lebih dari sepuluh tahun di pesisir pantai utara Kabupaten Pekalongan telah menyebabkan 11 desa yang tersebar di 3 kecamatan mengalami berbagai 
dampak ekonomi, sosial dan budaya. Karangjompo adalah salah satu desa di kecamatan Tirto yang mengalami bencana banjir, dimana lebih dari 70 persen wilayahnya terdampak banjir. Hampir semua fasilitas umum yang ada di desa Karangjompo mengalami kerusakan. Jalan desa, balaidesa, rumah ibadah dan bangunan sekolah harus mengalami perbaikan hamper tiap tahun. Begitupun dengan rumah warga. Untuk menghindari genangan banjir, mayoritas warga di desa Karangjompo telah mengupayakan pengurugan atau peninggian di rumahnya masing-masing.

Bencana banjir di wilayah ini disebabkan oleh faktor alam dan non alam. Bencana alam adalah bencana yang diakibatkan oleh peristiwa atau serangkaian peristiwa yang disebabkan oleh alam (Asy'ari, 2018), dalam hal ini adalah musim hujan dan siklus naiknya gelombang air pasang yang masuk ke daratan atau air rob. Musim hujan dan musim rob adalah siklus yang sudah ada sejak ratusan bahkan ribuan tahun yang lalu. Datangnyapun sudah bisa diprediksi, sehingga bisa diantisipasi. Tetapi nyatanya banjir ini menjadi tidak terkendali selama lebih dari sepuluh tahun belakangan. Hal ini karena dipicu oleh perilaku masyarakatnya yang memperburuk bencana karena abai terhadap kelestarian lingkungan. Oleh sebab itu bisa dikatakan bahwa selain karena faktor alam, bencana banjir di Pekalongan juga disebabkan oleh non alam, yaitu bencana yang diakibatkan oleh peristiwa atau rangkaian peristiwa nonalam (Asy'ari, 2018), termasuk akibat ulah manusia. Rendahnya kesadaran masyarakat menjadi faktor dominan yang menjadikan kerusakan lingkungan (Karim, 2017).

Lingkungan bagi manusia merupakan salah satu unsur yang sangat penting dalam kehidupannya, interaksi antara manusia dan lingkungan yang terjadi secara terus menerus, akan mempengaruhi perilaku manusia terhadap lingkungan. Sikap dan perilaku manusia akan menentukan baik buruknya kondisi suatu lingkungan. Cara manusia memperlakukan lingkungannya akan berdampak pada kualitas hidup masyarakat itu sendiri (Hamzah dalam Palupi, 2017).

Kurangnya kesadaran dan pemahaman masyarakat tentang kebijakan kepesisiran, tingkat pendidikan masyarakat yang rendah, watak masyarakat, serta tekanan biaya hidup menyebabkan masyarakat pesisir sering melakukan perusakan lingkungan pesisir (Primyastanto et al, dalam Maulana, 2018). Budaya masyarakat yang masih membuang sampah dan limbah secara sembarangan telah menyebabkan kurang berfungsinya saluran drainase dan sungai-sungai yang ada di wilayah ini. Para pengrajin batik juga terbiasa membuang limbah batiknya langsung ke saluran pembuangan tanpa melalui pemprosesan limbah terlebih dahulu dengan alasan akan semakin memberbesar biaya produksi.

Perilaku yang demikian itu telah menyebabkan saluran air dan sungai-sungai tercemar oleh limbah dan tersumbat oleh sampah. Pencemaran kemudian meresap kedalam pori-pori tanah danmempengaruhi kualitas air di sumur-sumur warga. Air sumur menjadi berubah warna dan rasa, tak jarang juga berbau. Dengan begitu, air sumur tidak layak lagi untuk digunakan apalagi untuk dikonsumsi.

Untuk membantu warga mendapatkan sumber air yang bersih dan sehat, pemerintah membuat program Penyediaan Air Minum dan Sanitasi Berbasis Masyarakat (Pamsimas). Program ini memang terbukti dapat mensuplay kebutuhan air bersih bagi warga. Tetapi sayangnya, sumber air pamsimas diambil dari air di kedalaman puluhan bahkan ratusan meter di bawah permukaan tanah. Hal inilah yang kemudian menjadi permasalahan lanjutan yang harus dihadapi oleh wilayah ini.

Di saat perilaku membuang sampah dan limbah belum mengalami perubahan kearah yang positif, sekarang ditambah dengan perilaku menggunakan air bawah tanah tanpa mengetahui akibat yang ditimbulkannya. Sebagaimana sudah dinyatakan dalam berbagai hasil penelitian yang menyebutkan bahwa salah satu penyebab banjir di pesisir Pekalongan adalah land subsidence, yaitu turunnya kedudukan permukaan tanah yang disebabkan oleh kompaksi tanah 
(Wei dalam Prasetyo \& Subiyanto, 2020), atau terjadinya penurunan tanah akibat pengambilan air tanah (groundwater extraction) secara besa-besaran yang melebihi kemampuan pengambilannya (Metasari, 2010 dalam Archenita et al., 2015).

Salah satu cara agar banjir tidak semakin parah, maka harus ada perubahan sikap dan perilaku pada warganya. Oleh sebab itu, perlu ada upaya yang dilakukan untuk menumbuhkan kesadaan, merubah sikap dan mendorong terjadinya perubahan perilaku pada warga.

Sikap adalah suatu hal yang menentukan sifat, hakikat, baik perbuatan sekarang maupun yang akan datang (Ahmadi, 2007). Sikap seseorang berkecenderungan bersifat konsisten dan sulit berubah (Kriyantono, 2014). Sikap timbul karena ada stimulus, yaitu bentuk fisik, visual atau komunikasi verbal yang dapat mempengaruhi tanggapan individu (Setiadi, 2008). Oleh sebab itu, untuk dapat merubah sikap menuju kearah terjadinya perubahan perilaku, maka diperlukan stimulus yang konsisten dan terus menerus. Salah satu strategi komunikasi yang dapat digunakan untuk menyampaikan stimulus kepada target sasaran adalah dengan kampanye.

Kampanye adalah serangkaian kegiatan komunikasi yang terorganisir dengan tujuan untuk menciptakan dampak tertentu terhadap sebagian khalayak sasaran secara berkelanjutan dalam periode waktu tertentu (Rogers \& Storey dalam Ruslan, 2008). Kampanye sangat berpengaruh terhadap perubahan sikap (Fatkhuri dalam Mana \& Cangara, 2016).

Agar pesan kampanye dapat diterima dengan baik oleh target sasaran, maka diperlukan pemilihan media yang tepat. Dalam kampanye ini media tanaman dianggap sebagai media yang tidak hanya sebagai saluran penyampai pesan tetapi sekaligus sebagai pesan itu sendiri. Sebagaimana dikatakan oleh McLuhan the medium is the message, sebab media atau saluran komunikasi menentukan substansi dari proses komunikasi (Saefudin, 2015).

\section{METODE}

Tahapan yang dilakukan dalam kegiatan pengabdian ini terbagi kedalam 6 tahap, yaitu (1) Pengumpulan data dengan FGD, (2) persaiapan penanaman, (3) penanaman, (4) produksi pesan, (5) pembagian tanaman, dan (6) evaluasi program. Untuk menyelesaikan lima tahapan tersebut diperlukan waktu enam bulan.

1. FGD

Sebagai langkah awal kampanye, tim pengabdian mengundang 46 perwakilan warga yang kesemuanya adalah ibu-ibu anggota arisan dalam acara Focus Group Discussion yang tujuannya adalah untuk mendapatkan informasi awal mengenai sikap warga tentang permasalahan banjir, land subsidence, dan permasalahan lingkungan pada umumnya.

2. Persiapan Penanaman

Dalam tahap persiapan ini tim pengabdian masyarakat melakuan proses pengamatan dan diskusi dengan beberapa penjual tanaman untuk menentukan tanaman akan ditanam. Selanjutnya tim pengabdian membeli pot yang akan digunakan sebagai wadah tanaman, membeli tanah merah, membeli sekam padi dan pupuk kandang.

3. Penanaman

Tanaman yang sudah dibeli kemudian ditanam di pot berukuran diameter $50 \mathrm{~cm}$, dengan media tanam tanah dicampur dengan sekam padi dan pupuk kandang dengan komposisi 40:30:30.

4. Produksi pesan 
Inti dari kampanye adalah penyampaikan pesan untuk memberikan stimulus agar dapat dipersepsi. Disini pesan disusun berdasarkan hasil FGD pada tahap pertama. Pesan dibuat dengan tujuan untuk menginformasikan dan mempersuasi warga desa Karangjompo untuk lebih peduli dengan permasalahan lingkungan.

\section{Pembagian tanaman}

Tanaman yang sudah ditanam di pot dan diberi pesan kampanye selanjutnya dibagikan atau diletakkan di sepanjang Jalan Raya Karangjompo Gg. Masjis Annur. Jalan ini merupakan salah satu jalan utama desa.

6. Evaluasi

Tahapan akhir dari kegiatan ini adalah dengan melakukan evaluasi, untuk mengukur sejauhmana perubahan sikap dan perilaku pada warga. Evaluasi dilakukan dengan cara FGD.

\section{HASIL DAN PEMBAHASAN}

Program kampanye komunikasi lingkungan ini dilakukan dalam waktu enam bulan, dimulai bulan Mei sampai dengan November 2020. Pada tanggal 8 Mei pukul 15.30 sampai dengan 17.00 WIB, tim pengabdian melakukan kegiatan focus group discussion dengan mengundang 46 ibu-ibu arisan. Kegiatan ini bertujuan untuk memperoleh informasi awal mengenai sikap warga tentang permasalahan banjir dan land subsidence.

Dari hasil FGD ini didapat informasi bahwa sebagian besar warga belum memahami secara lebih rinci mengenai penyebab banjir di desanya. Umumnya mereka beranggapan bahwa banjir disebabkan oleh hujan dan rob. Padahal ada sebab lain selain kedua faktor alam tersebut, salah satunya adalah land subsidence. Warga belum memahami bahwa selama ini mereka telah berkontribusi terhadap terjadinya land subsidence, yaitu melalui aktivitas mengambil air tanah untuk keperluan rumah tangganya tanpa control. Pertimbangan warga ketika menggunakan air pamsimas adalah semata-mata karena jumlah tagihan yang harus mereka bayarkan. Ukuran sedikit banyaknya penggunaan air adalah dilihat dari kemampuan membayar. Singkatnya, sepanjang warga mampu membayar tagihan air, maka sebanyak itulah mereka menggunakan air. Warga belum memiliki pertimbangan lingkungan, bahwa semakin banyak mereka menggunakan air maka semakin mereka berkontribusi terhadap laju penurunan permukaan tanah, yang artinya semakin memperburuk banjir.

Selain itu, masih banyak warga yang melakukan pembiaran terhadap aktivitas pembuangan sampah dan limbah secara sembarangan. Mereka sadar itu salah, tapi mereka belum mau melakukan tindakan apa-apa. Misalkan, masih banyak pengrajin batik yang membuang limbah batiknya langsung ke saluran air. Warga tahu bahwa tindakan itu salah, karena dari tindakan itulah yang menyebabkan sumur-sumur warga tercemar. Tetapi warga tetap melakukan pembiaran dengan alasan sungkan atau ewuh pakewuh.

Contoh lainnya adalah, masih banyak anak-anak usia sekolah yang terbiasa membuang sampah sembarangan. Kebiasaan itu tentunya adalah hasil dari pola didik orang tuanya di rumah dan guru-guru di sekolah. Para orang tua dan guru baru mengajarkan anak-anak secara verbal, tetapi minim contoh keteladanan yang nyata. Dua contoh ini mengindikasikan bahwa warga masih memiliki sikap yang acuh terhadap permasalahan lingkungan yang menyebabkan banjir.

Berdasarkan hasil FGD tersebut, tim pengabdian menyimpulkan bahwa ada dua sikap warga yang perlu dipengaruhi, yang pertama adalah sikap mengenai perilaku membuang 
sampah dan limbah sembarangan dan kedua sikap mengenai perilaku penggunaan air pamsimas yang tidak memperhitungkan aspek lingkungan.

Setelah informasi penting tersebut didapat, selanjutnya tim pengabdian masyarakat melakukan pengamatan ke sentra penjualan tanaman hias di Kecamatan Karanganyar dan melakukan diskusi kecil dengan beberapa penjual tanaman mengenai jenis tanaman yang dapat ditanam di pot dan mudah beradaptasi di lingkungan pesisir utara Pekalongan yang cuacanya cukup panas. Penggunaan pot diperlukan mengingat lahan di halaman rumah warga desa Karangjompo sudah tidak layak untuk ditanami. Sedangkan jalan desa sudah tidak memiliki bahu jalan karena sudah di hot mix.

Dari 3 kali hasil pengamatan dan diskusi dengan penjual tanaman, maka diputuskan membeli 4 jenis tanaman yaitu, bunga nusa indah warna pink dan putih, bunga melati jepang, bunga asoka warna merah dan kuning, serta bunga alamanda. Total ada 50 tanaman yang dibeli dalam 2 tahap pembelian. Selanjutnya tim pengabdian membeli 50 pot plastic dengan diameter $50 \mathrm{~cm}$. Pot plastic dipilih karena harganya yang terjangkau dan memiliki masa pakai yang cukup lama karena tidak mudah pecah. Proses pengamatan, pembelian tanaman dan pembelian pot memerlukan waktu sekitar 6 minggu.

Ketika tahap pemilihan dan pembelian tanaman telah selesai, selanjutnya adalah proses penanaman. Pada tahap ini tim pengabdian masyarakat dibantu oleh beberapa warga desa yang bergotong royong mengisi pot dengan tanah merah, sekam padi dan pupuk kandang dengan kompisisi 40:30:30. Selanjutnya tanaman yang sudah dibeli dipindahkan kedalam pot.

Bersamaan dengan tahap penanaman pohon, tim pengabdain masyarakat juga mulai melakukan proses penyusunan pesan. Dalam penyusuna pesan, ada tiga hal yan yang dilakukan yaitu (1) Merencanakan pesan, (2) mengorganisasikan pesan, dan (3) merevisi pesan sebelum disebarkan. Pada tahap merencanakan pesan, tim pengabdian menetapkan tujuan, dan menentukan ide pokok. Hasil FGD yang sudah dilakukan diawal sangat membantu dalam tahap merencanakan pesan. Agar pesan nantinya bisa diterima dengan baik, maka organisai pesan dibuat dengan cara mengelompokkan beberapa ide kedalam dua jenis pesan, yaitu pesan informative dan persuasive. Dari beberapa kelompok ide kemudian disusun menjadi pesan yang singkat, padat dan jelas, untuk kemudian diaplikasikan kedalam templet desain pamphlet.

Tabel 1. Jenis Informasi

\begin{tabular}{|c|c|c|c|c|}
\hline \multicolumn{3}{|c|}{ Pesan Informatif } & \multicolumn{2}{|c|}{ Pesan Persuasif } \\
\hline Penyebab banjir & Land Subsidence & & $\begin{array}{l}\text { Perilaku membuang } \\
\text { sampah dan limbah }\end{array}$ & $\begin{array}{l}\text { Perilaku menggunakan } \\
\text { air }\end{array}$ \\
\hline $\begin{array}{l}\text { - Faktor alam } \\
\text { - Faktor non alam }\end{array}$ & $\begin{array}{l}\text { - Pengertian } \\
\text { subsidence } \\
\text { - Penyebab } \\
\text { subsidence } \\
\text { - Akibat } \\
\text { subsidence }\end{array}$ & $\begin{array}{l}\text { land } \\
\text { land } \\
\text { land }\end{array}$ & $\begin{array}{lr}\text { - } & \text { Mengajak membuang } \\
& \text { sampah } \\
\text { tempatnya } & \text { pada } \\
\text { - } & \text { Mengajak menjaga } \\
\text { kebersihan } & \text { saluran } \\
\text { drainase } & \\
\text { - } & \text { Mengajak saling } \\
& \text { mengingatkan tentang } \\
& \text { kebersihan lingkungan }\end{array}$ & 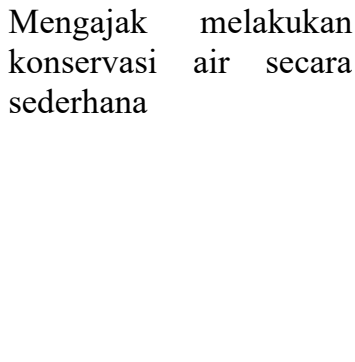 \\
\hline
\end{tabular}

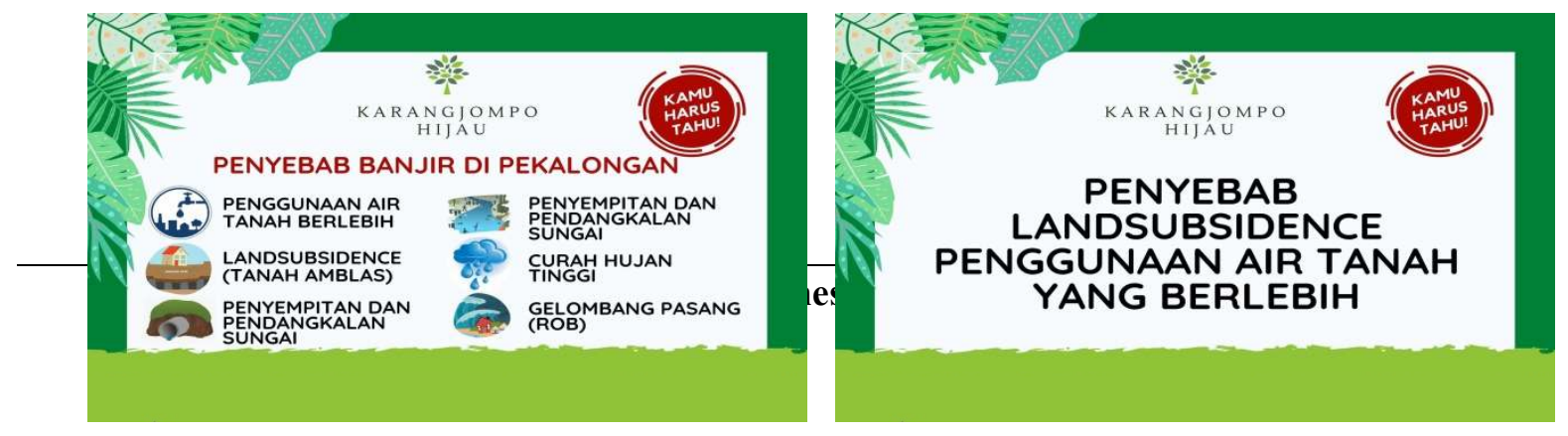



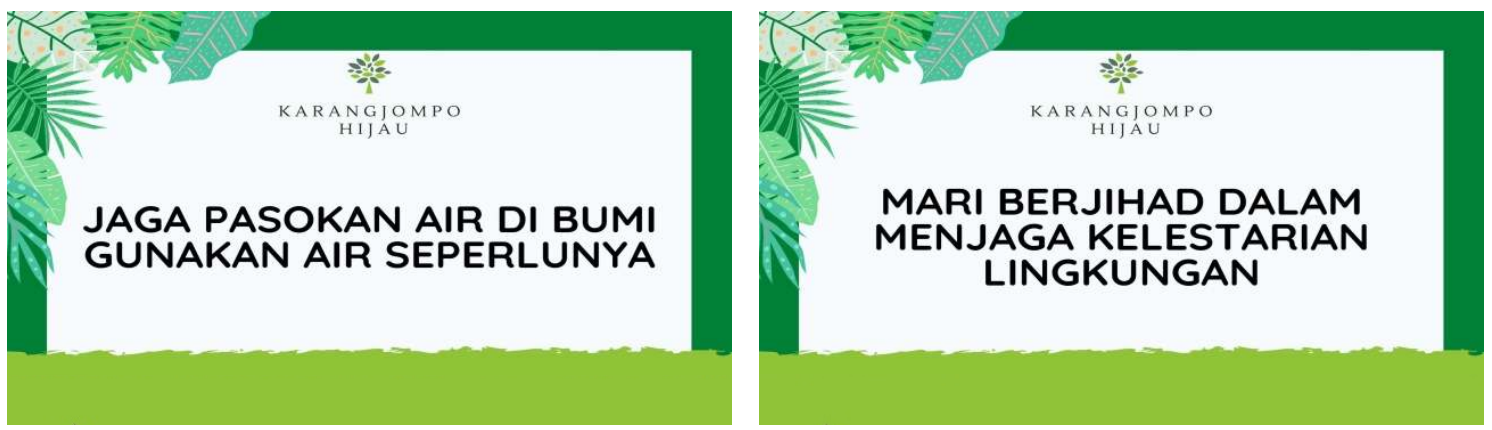

Gambar 1. Desain Pesan Kampanye
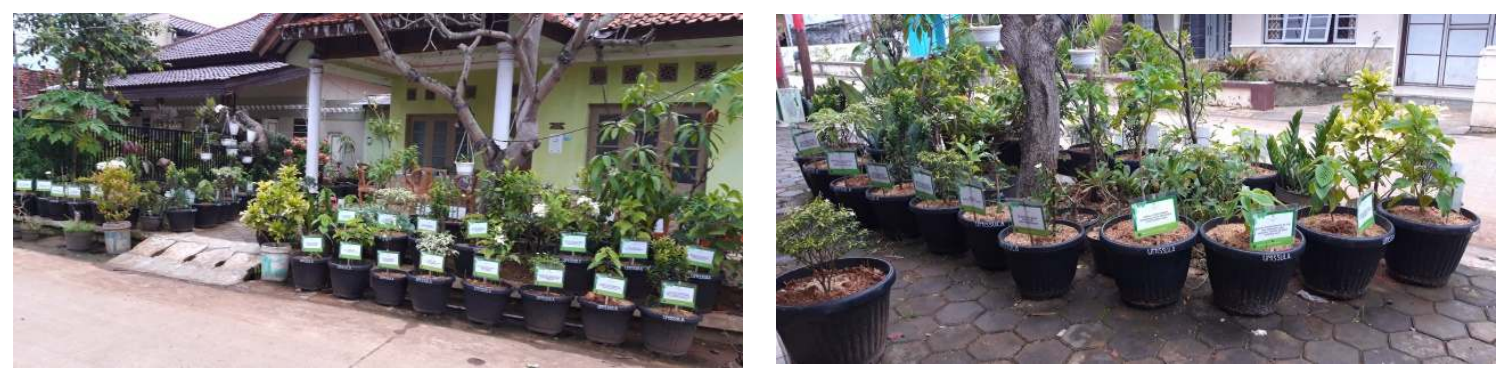

Gambar 2. Media Tanaman dengan Pesan Kampanye

Setelah semua tanaman ditanam di dalam pot dan dipasangkan pesan kampanye, berikutnya tanaman-tanaman ini dipasang di sepanjang jalan Raya Karangjompo Gg Masjid Annur sepanjang kurang lebih 300 meter dengan jarak antara masing-masing pot kurang lebi 3 meter. Sebenarnya jarak ini kurang ideal, karena dalam tahap perencanaan awal, akan dipasang 100 tanaman pot beserta pesan kampanyenya di sepanjang jalan raya Karangjompo, tetapi ternyata anggaran tidak mencukupi.

Tanaman dalam pot beserta pesan kampanye ini telah terpasang selama kurang lebih 4 bulan. Warga menanggapinya dengan senang karena sekarang di sepanjang penutup saluran drainase di depan rumahnya telah terpajang tanaman yang tidak saja mempercantik jalan tetapi juga mempercantik halaman. Warga menunjukkan partisipasi yang cukup baik dalam menyirami tanaman minimal satu kali dalam sehari. Dan selama empat bulan belum ada satupun tanaman yang mati. Dan untuk memastikan bahwa pesan betul-betul sampai kepada warga, maka desain pesan yang dibuat dalam format "jpeg" juga dikirimkan melalui pesan broadcast kepada group-group WhatsApps seperti group arisan, posyandu, pamong desa, dan lain-lain.

Sayangnya permasalahan pemeliharaan tanaman dengan pesan kampanye komunikasi lingkungan justru datang dari siswa sekolah, yang sebenarnya bukan target sasaran kampanye. Perlu diketahui bahwa di jalan Raya Karangjompo terdapat sebuah sekolah dasar dimana siswa/inya masuk secara bergilir selama masa pandemi Covid-19. Kerika mereka berangkat atau 
pulang sekolah, kadang tangannya berbuat jahil dengan cara mematahkan beberapa daun ataupun ranting tanaman, melepas atau menyobek pesan kampanye yang ada di pot tanaman.

Sebagai tahap akhir dari rangkaian tahapan program pengabdian ini, maka pada tanggal 27 November 2020, tim pengabdian melakukan evaluasi kegiatan kampanye dengan cara meminta tanggapan dari ibu-ibu anggota arisan dalam acara arisan bulanan yang diselenggarakan disalah satu rumah warga. Dalam acara arisan yang di setting menjadi acara diskusi tersebut tampak terlihat bahwa sudah ada perubahan sikap pada masyarakat mengenai permasalahan banjir dan land subsidence. Hampir seluruh anggota arisan yang hadir menyatakan sekarang sudah mengerti bahwa banjir tidak hanya disebabkan oleh hujan dan rob tetapi juga disebabkan oleh beberapa faktor lain, salah satunya land subsidence. Warga juga sudah mengetahui bahwa salah satu penyebab terjadinya land subsidence adalah adanya penggunaan air bawah tanah secara berlebihan. Mereka juga sudah memiliki kecenderungan untuk bertindak dengan memperhatikan aspek kelestarian lingkungan. Artinya, telah terjadi perubahan sikap baik itu kognisi, afeksi maupun konasi. Sayangnya perubahan tersebut belum berhasil mendorong warga untuk melakukan tindakan sesuai dengan sikap yang diyakininya. Kesadaran itu masih ada didalam pikirannya, belum pada perilakunya.

Waktu kampanye yang sangat singkat, yaitu hanya empat bulan sepertinya belum mampu untuk merubah perilaku warga desa Karangjompo, Selain itu sifat kampanye komunikasi yang cencerung satu arah, kurang bisa mendorong keterlibatan warga didalam memecahkan permasalahan banjir. Akan lebih baik bila dikombinasikan dengan bentuk komunikasi lain yang sifatnya dua arah timbal balik seperti program pelatihan konservasi air sekala rumah tangga, atau program penyuluhan secara berkala yang memungkinkan terjadinya tanya jawab dan dialog dengan warga.

\section{KESIMPULAN}

Setelah empat bulan kampanye komunikasi lingkungan dengan media tanaman dilakukan di desa Karangjompo Kecamatan Tirto menghasilkan kesimpulan bahwa warga desa Karangjompo merasa senang dengan kegiatan ini karena mereka mendapatkan tanaman secara gratis yang ditata di pinggir jalan depan rumahnya. Dari hasil kampanye juga telah menunjukkan adanya perbahan sikap kognitif, afektif dan konatif, tetapi belum menunjukkan perubahan behavioral.

\section{UCAPAN TERIMAKASIH}

Kegiatan ini merupakan bagian dari program pengabdian masyarakat yang diselenggarakan oleh program studi Ilmu Komunikasi Unissula dengan biaya dari LPPM Unissula. Oleh sebab itu penulis mengucapkan terimakasih kepada LPPM Unissula yang telah mendukung terlaksananya pengabdian ini.

\section{DAFTAR PUSTAKA}

Ahmadi, A. (2007). Psikologi sosial. Rineka Cipta.

Archenita, D., Nengsih, S., Hamid, D., Natalia, M., \& Misriani, M. (2015). Kajian Land Subsidence Untuk Perkuatan Tanah (Studi Kasus Sawahlunto). Jurnal Rekayasa Sipil Politeknik Negeri Andalas, 12(2), 10-18. 
Asy'ari, Q. (2018). Analisis Dampak Sosial Ekonomi Pasca Bencana di Kabupaten Pamekasan (Studi Kasus Banjir, Longsor dan Kekeringan di Pamekasan 2007). J-MACC: Journal of Management and Accounting, 1(2), 153-168.

Karim, A. (2018). Mengembangkan kesadaran melestarikan lingkungan hidup berbasis humanisme pendidikan agama. Edukasia: Jurnal Penelitian Pendidikan Islam, 12(2), 309-330.

Kriyantono, R. (2014). Teori public relations perspektif barat dan lokal. Kencana Prenada Media Grup.

Mana, P. M., \& Cangara, H. (2016). Strategi Komunikasi Kampanye Pengendalian Minuman Beralkohol (Perda Nomor 11 Tahun 2012) oleh Pemerintah Kabupaten Sikka. KAREBA: Jurnal Ilmu Komunikasi, 3(2), 133-141.

Maulana, L. H., \& Hendrawan, A. (2018). Kajian Perilaku Masyarakat Pesisir yang Mengakibatkan Kerusakan Lingkungan (Studi Kasus di Pantai Kutawaru, Kecamatan Cilacap Tengah Kabupaten Cilacap). Saintara: Jurnal Ilmiah Ilmu-Ilmu Maritim, 3(1), 28-38.

Palupi, T. (2017). Hubungan antara sikap dengan perilaku pro-lingkungan ditinjau dari perspektif theory of planned behavior. In Proceeding Biology Education Conference: Biology, Science, Enviromental, and Learning (Vol. 14, No. 1, pp. 214-217).

Prasetyo, Y., \& Subiyanto, S. (2014). Studi Penurunan Muka Tanah (Land Subsidence) Menggunakan Metode Permanent Scatterer Interferometric Synthetic Aperture Radar (PsInsar) di Kawasan Kota Cimahi-Jawa Barat. Jurnal Teknik Geodesi Universitas Diponegoro: Semarang.

Ruslan, R. (2008). Kiat dan strategi kampanye public relations. PT. Rosdakarya.

Saefudin, A. (2008). Perkembangan Teknologi Komunikasi: Perspektif Komunikasi Peradaban. Mediator: Jurnal Komunikasi, 9(2), 383-392.

Setiadi, N. J. (2008). Perilaku konsumen (konsep dan implikasi untuk strategi dan penelitian pemasaran). Kencana Prenada Media Grup. 